\title{
ANALISIS PENDEKATAN SAINTIFIK PADA PEMBELAJARAN BAHASA INDONESIA DI SMP NEGERI 2 SECANGGANG \\ TAHUN PEMBELAJARAN 2018/2019
}

\author{
Irmalisa Sirait (irmalisa2301@gmail.com) \\ Frinawaty L. Barus (frinabarus@unimed.ac.id) \\ Universitas Negeri Medan
}

\begin{abstract}
ABSTRAK
Pendekatan saintifik lahir dengan mengadaptasi scientific learning. Istilah scientific learning diadaptasikan ke Indonesia menjadi pembelajaran saintifik atau disebut juga sebagai pembelajaran ilmiah. Penelitian ini bertujuan untuk mengetahui proses pembelajaran menggunakan pendekatan saintifik yang dilakukan oleh guru pada pembelajaran bahasa Indonesia di SMP Negeri 2 Secanggang. Penelitian menggunakan metode kualitatif. Penerapan pendekatan saintifik yang dilakukan oleh guru I sangat baik dengan persentase 90 $\%$, guru II dalam kategori cukup baik dengan persentase $77,5 \%$, begitu juga dengan guru III dalam kategori cukup baik dengan persentase 72,5 $\%$. Maka, dapat disimpulkan bahwa penerapan pendekatan saintifik yang dilaksanakan di SMP Negeri 2 Secanggang sudah cukup baik.Dari hasil penelitian dalam penerapan pendekatan saintifik, aspek $5 \mathrm{M}$ yaitu mengamati, menanya, mencoba, menalar, dan mengomunikasikan yang ada pada pendekatan santifik guru rata-rata hanya melaksanakan $3 \mathrm{M}$ yaitu mengamati, mengumpulkan informasi atau mencoba, dan mengkomunikasikan atau menyajikan dalam pembelajaran bahasa Indonesia.
\end{abstract}

Kata kunci : Pendekatan Saintifik, Guru Bahasa Indonesia

\section{PENDAHULUAN}

Pembelajaran merupakan suatu proses yang rumit karena tidak sekedar menyerap informasi dari guru, tetapi juga melibatkan berbagai kegiatan dan tindakan yang harus dilakukan untuk mencapai hasil belajar yang baik. Kunci pokok dalam sebuah pembelajaran adalah seorang guru. Guru menjadi subjek yang memiliki tugas, tanggung jawab, dan inisiatif pengajaran. Guru dapat mengelola kegiatan belajar dengan maksimal secara efektif dan efisien untuk meningkatkan kemampuan siswa.

Pembelajaran bahasa Indonesia dalam Kurikulum 2013 tidak hanya difungsikan sebagai alat komunikasi, tetapi juga sarana berpikir. Pembelajaran merupakan proses interaksi peserta didik dengan 
pendidik dan sumber belajar pada suatu lingkungan belajar agar terjadi proses pemerolehan ilmu dan pengetahuan, serta pembentukan sikap dan kepercayaan pada peserta didik (Amri, 2013:34). Proses pembelajaran akan berjalan dengan baik apabila mampu mengubah peserta didik serta mampu menumbuh kembangkan kesadaran peserta didik untuk belajar, sehingga pengalaman yang diperoleh peserta didik saat terlibat proses pembelajaran dapat merasakan manfaat secara langsung bagi perkembangan pribadinya.

Kurikulum dan pembelajaran merupakan dua hal yang berkaitan erat. Kurikulum pada dasarnya merupakan perencanaan menyeluruh yang mencakup kegiatan dan pengalaman yang perlu disediakan dan memberikan kesempatan secara luas bagi siswa untuk belajar.

Kurikulum 2013 merupakan langkah positif pemerintah merevitalisasi pendidikan karakter dalam seluruh jenis dan jenjang pendidikan. Kurikulum 2013 lebih menekankan pada pendidikan karakter. Pengembangan Kurikulum 2013 merupakan kurikulum yang berbasis karakter dan kompetensi, dengan demikian dapat menghasilkan generasi yang betulbetul produktif, kreatif, inovatif, dan berkarakter. Kurikulum 2013 menitik beratkan pada kemampuan siswa yang aktif dalam proses pembelajaran.

Kurikulum

menganjurkan agar digunakan pendekatan ilmiah dalam proses pembelajaran. Dengan pendekatan ini, diharapkan hasil pembelajaran lebih melekat pada pikiran siswa karena mereka melakukannya dengan prosedur berbasis fakta. Sebagaimana prosedur yang dilakukan dalam penelitian ilmiah, pembelajaran berbasis pendekatan ilmiah dilakukan dalam beberapa tahap, mulai dari mengamati, menanya, menalar, mencoba, menyimpulkan, serta mengomunikasikan (Kemendikbud, 2013b).

Pembelajaran dengan pendekatan saintifik dimaksudkan untuk memberikan pemahaman kepada peserta didik dalam mengenal, memahami berbagai materi menggunakan pendekatan ilmiah, bahwa informasi bisa berasal 
dari mana saja, kapan saja, tidak bergantung informasi searah dari guru (Hosnan, 2014:34). Proses pembelajaran dengan pendekatan saintifik harus dipandu dengan kaidah-kaidah pendekatan ilmiah.

Melalui

pendekatan

saintifik/ilmiah, selain dapat menjadikan siswa lebih aktif dalam mengkonstruksi pengetahuan dan keterampilannya, juga dapat mendorong siswa untuk melakukan penyelidikan guna menemukan fakta-fakta dari suatu fenomena atau kejadian. Artinya, dalam proses pembelajaran, siswa dibelajarkan dan dibiasakan untuk menemukan kebenaran ilmiah, bukan diajak untuk beropini apalagi fitnah dalam melihat suatu.

Sesuai dengan kegiatan observasi yang dilakukan oleh peneliti di SMP Negeri 2 Secanggang pada tanggal 5 Mei 2018. Sekolah tersebut sudah menggunakan Kurikulum 2013. Akan tetapi, untuk kelas IX masih menggunakan KTSP dan rencananya tahun pembelajaran baru semua kelas akan menggunakan kurikulum 2013. Guru yang ada di sekolah tersebut berjumlah 33 orang dan siswanya berjumlah 706 siswa.

Observasi yang dilakukan peneliti kepada 3 guru bahasa Indonesia di SMP Negeri 2 Secanggang tentang pendekatan saintifik diantaranya bernama Bapak Tri mengatakan bahwa pada kurikulum 2013 memang menuntut untuk melakukan pendekatan saintifik dan sebagian guru sudah menerapkannya, akan tetapi ada kendala-kendala yang dihadapi seperti kesiapan guru dalam kurikulum 2013 karena pelatihanpelatihannya masih belum optimal. Kemudian siswanya juga masih kurang berminat dalam membangun saintifik itu sendiri. Karena, untuk membangkitkan saintifik dalam diri siswa baik guru maupun siswa harus saling memahami, apalagi kebanyakan siswa yang aktif dalam kelas hanya beberapa orang saja dan cenderung dengan orang yang sama. Sehingga guru juga harus tetap memberikan penjelasan terhadap materi yang akan disampaikan.

Kemudian Bapak Juli mengatakan bahwa proses pendekatan saintifik yang dilakukan di dalam kelas sudah terlaksana 
antara siswa dan guru. Akan tetapi, hal ini bisa dikatakan relatif karena kebanyakan siswa yang aktif cenderung dengan orang yang sama.

Karena siswa memiliki kemampuan yang berbeda-beda. Hal ini disebabkan ketidakpahaman siswa terhadap materi yang dipelajari, tidak bisa jika siswa dituntut untuk mencari atau menggali sendiri pengetahuan tentang materi tersebut, guru harus tetap memberikan metode ceramah kepada siswa agar siswa mengerti. Biasanya dengan begitu siswa akan mulai mencari atau bertanya terkait dengan materi yang disampaikan.

Bapak Juli juga mengatakan walaupun sedikit demi sedikit pembelajaran kurikulum 2013 dijalankan, akan tetapi memang sulit untuk mencapai proses pembelajaran yang sesuai dengan kurikulum 2013. Guru sendiri juga sudah mendapatkan pelatihan kurikulum 2013 seperti MGMP. Namun, ada beberapa kendala dalam menerapkan kurikulum 2013 seperti guru harus mampu menilai siswa secara individu karena kemampuan setiap siswa berbeda-beda, sarana dan prasarana yang mendukung pembelajaran kurikulum 2013 masih minim dan ini akan menghambat proses pembelajaran. Maka dari itu, guru harus mampu membuat siswa itu menjadi tertarik pada pembelajaran.

Sedangkan Ibu Isma mengatakan bahwa pendekatan saintifik pada pembelajaran bahasa Indonesia umumnya sudah dilaksanakan karena itu sesuai dengan Kurikulum 2013 yang berlaku sekarang ini. Guru juga sudah mengikuti pelatihan mengenai kurikulum 2013 tapi tetap saja masih ada beberapa kendala seperti siswanya masih sulit untuk memahami jika hanya diberi sedikit penjelasan. Karena, kemampuan setiap siswa berbeda-beda. Jadi, guru harus mampu membuat suasana kelas menjadi aktif, berminat, dan semangat saat pembelajaran. Kemudian, untuk teknologi sendiri guru yang sudah lanjut usia juga masih kesulitan memahami teknologi, sarana dan prasarananya juga kurang memadai. Adanya pendekatan saintifik pada pembelajaran bahasa Indonesia dapat melatih siswa untuk aktif sesuai dengan 5M yang diterapkan pada pendekatan saintifik. Sehingga, siswa 
akan mencari sendiri informasi dan cara mengatasinya masalah yang ada.

Sejauh ini kurikulum 2013 sudah dijalankan dengan semaksimal mungkin walaupun tidak sempurna.

Sejalan dengan hasil observasi tersebut diketahui kesulitan yang didapat guru terkait pelaksanaan pembelajaran di kelas belum tampak kebiasaan peserta didik melalui kelima langkah yang terinci dalam pendekatan saintifik, apalagi pengembangan model-model pembelajarannya. Kemudian, kurangnya kesiapan guru dalam menghadapi serta melaksanakan kurikulum 2013, serta sarana dan prasarana pada pembelajaran berbasis pendekatan saintifik yang sesuai dengan kurikulum 2013. Terkait hal-hal tersebut keterampilan guru pada pembelajaran pendekatan saintifik perlu mendapat perhatian dan lebih ditingkatkan lagi.

Permendikbud No. 65 Tahun 2013 tentang Standar Proses Pendidikan Dasar dan Menengah telah mengisyaratkan tentang perlunya proses pembelajaran yang dipandu dengan kaidah-kaidah pendekatan saintifik/ilmiah. Upaya penerapan pendekatan saintifik/ilmiah dalam proses pembelajaran ini sering disebut-sebut sebagai ciri khas dan menjadi kekuatan tersendiri dari keberadaan Kurikulum 2013.

Begitu juga dengan penelitian yang dilakukan oleh Purnama dkk tahun 2016 mengatakan bahwa terdapat variasi kemampuan guru dalam pelaksanaan pembelajaran dengan pendekatan saintifik, dan kemampuan guru dalam mengelola langkah mengamati belum optimal karena kekurangan sarana teknologi informatika sehingga langkah mengamati kurang variatif dan kemungkinan akan menimbulkan kejenuhan. Kemampuan guru dalam langkah menanya belum optimal ditandai dengan stimulasi yang diberikan guru belum direspon secara baik oleh peserta didik. Kemampuan guru dalam mengelola dan mengumpulkan informasi belum optimal karena terkendala oleh kemampuan sekolah menyelenggarakan sarana teknologi informatika. Kemampuan guru dalam mengelola langkah mengasosiasi telah kondusif. Kemampuan guru dalam mengelola langkah mengkomunikasikan belum optimal 
karena belum terjadinya penyelarasan tanggapan dan penyimpulan.

Penelitian yang sama juga dilakukan oleh Ni Luh Gede Riwan Putri Bintari, dkk tahun 2014 mengatakan bahwa kendala guru dalam menerapkan pembelajaran bahasa Indonesia berdasarkan pendekatan saintifik sesuai dengan kurikulum $2013 \quad$ adalah ketidaksesuaian antara waktu dengan materi pembelajaran. Materi pembelajaran sangat kompleks sedangkan waktu yang tersedia sangat terbatas. Kendala lain yaitu contoh-contoh yang disajikan pada buku pegangan siswa tidak kontekstual sehingga menyulitkan siswa menyerap materi pembelajaran.

Berdasarkan latar belakang di atas, maka penulis tertarik untuk menjadikan permasalahan tersebut sebagai topik yang akan diteliti. Adapun judul yang akan dipilih sesuai dengan materi tersebut ialah "Analisis Pendekatan Saintifik Pada Pembelajaran Bahasa Indonesia di SMP Negeri 2 Secanggang Tahun Pembelajaran 2018/2019".

\section{METODE PENELITIAN}

Penelitian ini menggunakan penelitian kualitatif, peneliti menggunakan metode penelitian kualitatif untuk dapat mendeskripsikan pendekatan saintifik (mengamati, menanya, menalar, mencoba, menyimpulkan, dan mengomunikasikan) dalam pembelajaran bahasa Indonesia pada guru di SMP Negeri 2 Secanggang.Aktifitas dalam analisis data, yaitu data reduction, data display, dan conclusion drawing/verification.

\section{HASIL PENELITIAN DAN PEMBAHASAN}

\section{A. Hasil Penelitian}

1. Deskripsi Lokasi Penelitian, Subjek, dan Waktu Pelaksanaan Penelitian

a. Lokasi Penelitian

Penelitian ini dilakukan di SMP Negeri 2 Secanggang, Stabat. SMP Negeri 2 Secanggang ini terletak di Jalan Pendidikan, Budi Utomo Desa Karang Anyar, Kecamatan Secanggang, Kabupaten Langkat. Lokasi ini bisa ditempuh dari Stabat atau Binjai kira-kira 30 menit. SMP Negeri 2 Secanggang ini 
pertama kali berdiri Tahun 1994.

SMP Negeri 2 Secanggang terletak diantara pemukiman warga. Di dekat sekolah juga terdapat puskesmas. SMP Negeri 2 Secanggang ini terletak diantara perbatasan Kabupaten Deli Serdang dan Kabupaten Langkat. Sehingga ada beberapa anak - anak yang berada di daerah Deli Serdang yang bersekolah di SMP Negeri 2 Secanggang.

b. Subjek Penelitian

Subjek penelitian ini yaitu guru bahasa Indonesia yang mengajar di SMP Negeri 2 Secanggang sebanyak 3 orang yaitu Bapak Tri Warsa Umbara, S. Pd., Bapak Juli Amri, S. Pd., dan Ibu Isma Ningsih, S. Pd. SMP Negeri 2Secanggang sudah melakukan penerapan kurikulum 2013 sejak tahun 2016, akan tetapi untuk kelas IX baru tahun ini menerapkan Kurikulum 2013. c. Waktu penelitian

Waktu penelitian dilakukan dimulai tanggal 4 September 2018 s.d. 13 September 2018. Observasi yang dilakukan oleh peneliti sebanyak 3 kali di SMP Negeri 2 Secanggang.

2. Deskripsi Penelitian Kurikulum 2013 sudah diterapkan di SMP Negeri 2 Secanggang pada tahun 2015 sampai sekarang. Akan tetapi, untuk kelas IX baru tahun 2018 ini diterapkan, sebelumnya kelas IX masih memakai kurikulum 2006 atau KTSP. Pendekatan saintifik sendiri pada pembelajaran bahasa Indonesia sudah diterapkan oleh guru sendiri. Berdasarkan data-data yang didapatkan oleh peneliti, maka hasil penelitian akan dijabarkan sebagai berikut: 
Tabel 1 Hasil Skor dan Persentase Analisis Pendekatan Saintifik

\begin{tabular}{c|c|c|c|c|c|c|c|c|c|c}
\hline \multirow{2}{*}{ Guru } & \multicolumn{7}{c|}{ Pendekatan Saintifik } & \multicolumn{2}{|c}{ Nilai } \\
\cline { 2 - 12 } & $\begin{array}{c}\text { Perenca- } \\
\text { naan }\end{array}$ & $\begin{array}{c}\text { Pendahu- } \\
\text { luan }\end{array}$ & $\begin{array}{c}\text { Menga- } \\
\text { mati }\end{array}$ & $\begin{array}{c}\text { Mena- } \\
\text { nya }\end{array}$ & $\begin{array}{c}\text { Men- } \\
\text { coba }\end{array}$ & $\begin{array}{c}\text { Mena- } \\
\text { lar }\end{array}$ & $\begin{array}{c}\text { Mengomu- } \\
\text { nikasikan }\end{array}$ & $\begin{array}{c}\text { Penu- } \\
\text { tup }\end{array}$ & Skor & $\begin{array}{c}\text { Persen- } \\
\text { tase }\end{array}$ \\
\hline I & SB & B & SB & B & SB & B & SB & B & 36 & $\begin{array}{c}90 \% \\
(\text { SB })\end{array}$ \\
\hline II & SB & B & B & SK & SB & CB & SB & B & 31 & $\begin{array}{c}77.5 \% \\
(\mathrm{CB})\end{array}$ \\
\hline III & SB & B & B & SK & SB & CB & SB & K & 29 & $\begin{array}{c}72,5 \% \\
(\mathrm{CB})\end{array}$ \\
\hline
\end{tabular}

Dari tabel 1 dapat dilihat persentase dari setiap kegiatan pelaksanaan pendekatan saintifik pada pembelajaran, rata-rata ketiga guru masih kurang dalam menerapkan pelaksanaan kegiatan menanya dan menalar. Terlihat seperti guru II, dan III masih kurang dalam melaksanakan kegiatan menanya dan menalar.

\section{B. Pembahasan}

Dari analisis yang telah dipaparkan, diperoleh hasil sebagai berikut:

Kegiatan perencanaan yang dilakukan oleh guru I, II, dan IIIsangatbaik. RPP yang dibuat juga sesuai dengan Kurikulum 2013. Hanya saja kendalanya ialah penerapan RPP itu sendiri terhadap materi pembelajaran dengan alokasi waktu yang sudah ditetapkan. Guru I sesuai dengan RPP metode yang digunakannya ialah diskusi, guru II menggunakan metode diskusi, dan guru III menggunakan metode tanya jawab, wawancara, diskusi, dan bermain peran.

Dari hasil penelitian pada kegiatan pendahuluan ketiga guru sudah melaksanakan kegiatan pendahuluan hampir menyeluruh tetapi masih ada beberapa hal yang kurang merata saat disampaikan seperti menyampaikan kompetensi yang akan dicapai dan teknik penilaian yang akan digunakan. Dapat disimpulkan bahwa guru sudah melaksanakan kegiatan pendahuluan dengan baik terlepas dari keadaan saat penerapannya. 
Kegiatan mengamati yang dilakukan oleh guru I sangat baik sedangkan guru II dan III sudah baik. Seperti yang dilakukan oleh guru I menayangkan materi pembelajaran lewat LCD Proyektor sesuai dengan pernyataan. Majid dan Rochman (2015:77) yang mengatakan bahwa:

"Kegiatan
mengamati, guru
membuka secara
luas dan bervariasi
kesempatan peserta
didik untuk
melakukan
pengamatan
melalui kegiatan:
melihat, menyimak,
mendengar, dan
membaca".

Sedangkan untuk guru II dan III media yang digunakan hanya berupa buku paket saja dan siswa mengamati materi pembelajaran yang terdapat pada buku. Hal ini sejalan dengan penelitian terdahulu yang dilakukan oleh Purnama dkk (2016) mengatakan bahwa terdapat variasi kemampuan guru dalam pelaksanaan pembelajaran dengan pendekatan saintifik, dan kemampuan guru dalam mengelola langkah mengamati belum optimal karena kekurangan sarana teknologi informatika.
Kegiatan menanya yang dilakukan oleh ketiga guru terbilang baik dan cukup baik. Mengenai kegiatan menanya menurut Daryanto (2014:64) mengatakan bahwa :

"Pada kegiatan
menanya guru
membuka
kesempatan secara
luas kepada siswa
untuk bertanya
mengenai apa yang
sudah dilihat,
disimak, dibaca,
atau dilihat".

Sesuai dengan pernyataan pendapat para ahli tersebut guru I dalam menerapkan kegiatan menanya sudah baik terlihat saat kegiatan pembelajaran guru I memancing rasa ingin tahu peserta didik dengan cara memberikan pertanyaan, memberikan kisi-kisi dari materi, dan membuka kesempatan bertanya untuk semua peserta didik.Guru I juga tidak monoton dalam memberikan materi sehingga peserta didik terlihat lebih antusias dalam mengemukakan pendapatnya

Berbeda dengan guru II dan III, kegiatan menanya yang dilakukan sangat kurang terlihat dari siswa yang pasif, jenuh, dan masih bingung soal materi pembelajaran. 
Dalam hal ini guru II dan III lebih banyak menggunakan metode ceramah dalam penyampaian materi. Memang, tidak bisa dipungkiri bahwa guru harus tetap menggunakan metode ceramah. Akan tetapi, jangan terlalu sering dalam menerapkannya. Hal ini mengakibatkan siswa menjadi tidak kritis dalam berpikir dan konsep pembelajaran yang peserta didik terapkan hanya menerima apa yang disampaikan oleh guru saja.

Hal ini sejalan dengan penelitian yang dilakukan oleh Muliatiana tahun 2016 mengatakan bahwa Hasilnya menunjukkan bahwa kendala yang dihadapi oleh guru adalah pada bagian menanya dengan persentase $50 \%$ jarang melakukan serta $50 \%$ sering melakukan. Hal ini disebabkan karena kurangnya motivasi guru terhadap peserta didik dan penggunaan waktu yang kurang efektif. Oleh karena itu disarankan kepada guru agar lebih banyak lagi memberikan perhatian kepada peserta didik dengan cara selalu memberi pujian kepada peserta didik apabila ada yang mau bertanya atau memberi saran. Apabila ada pertanyaan dari peserta didik selalu dihargai atau memberi respon dengan baik.

Kegiatan mencoba atau mengumpulkan informasi menurut Abidin, (2015:90), mengatakan bahwa:

"Aplikasi metode
eksperimen atau
mencoba
dimaksudkan untuk
mengembangkan
berbagai ranah
tujuan belajar yaitu
sikap, keterampilan
dan pengetahuan".

Kegiatan mencoba yang dilakukan oleh ketiga guru sudah sangat baik. Terlihat peserta didik yang dikelola oleh guru I antusias dalam mengerjakan tugas yang diberikan. Ketiga guru bersama peserta didik membicarakan masalah terkait materi pembelajaran dan menugaskan siswa untuk mengumpulkan informasi dari berbagai sumber, walaupun sumber pada saat penelitian hanya berupa buku saja yang digunakan oleh ketiga guru. Pada saat kegiatan mencoba, guru bertindak sebagai pengarah atau pengelola kegiatan belajar.

Kegiatan mengasosiasi dalam (Permendikbud Nomor 81A Tahun 
2013), adalah memproses informasi yang sudah dikumpulkan baik terbatas dari hasil kegiatan mengumpulkan/ eksperimen maupun hasil dari kegiatan mengamati dan kegiatan mengumpulkan informasi. Pengolahan informasi yang dikumpulkan dari yang bersifat menambah keluasan dan kedalaman sampai kepada pengolahan informasi yang bersifat mencari solusi dari berbagai sumber. Dalam hal ini guru I sudah baik dalam melaksanakan kegiatan menalar sedangkan guru II dan guru III cukup baik dalam melaksanakan kegiatan menalar pada pembelajaran bahasa Indonesia.

Hal ini sejalan dengan penelitian Darnius (2016) yang mengatakan bahwa guru juga jarang mengajak peserta didik untuk menyimpulkan apa yang telah mereka kumpulakn, guru di sini langsung menyuruh peserta didik untuk mengomunikasikan. Dengan adanya guru menyuruh peserta didik untuk menyimpulkan dulu sebelum mengomunikasikan, peserta didik lebih terlatih untuk terbiasa menarik kesimpulan dari hal-hal yang sedang mereka pelajari.
Kegiatan

mengkomunikasikan menurut Abdul Majid dan Choirul Rochman (2015: 92), mengatakan bahwa:

"Pada kegiatan akhir diharapkan peserta didik dapat mengkomunikasikan hasil pekerjaan yang telah disusun, baik secara bersama-sama dalam kelompok dan atau secara individu dari hasil kesimpulan yang dibuat bersama".

Dari hasil penelitian ketiga guru sudah melaksanakan kegiatan mengomunikasikan dengan sangat baik dengan memberikan kesempatan kepada peserta didik untuk menampilkan atau mempresentasikan hasil kerja di depan kelas baik secara berkelompok maupun individu.

Kegiatan penutup yang dilakukan oleh guru I dan II sudah baik seperti membuat rangkuman pembelajaran, melakukan refleksi kegiatan, dan menyampaikan materi pembelajaran yang akan datang. Akan tetapi, guru I dan II tidak melakukan evaluasi terhadap hasil pembelajaran. Sedangkan guru III kurang dalam melaksanakan kegiatan 
penutup. Guru III hanya membuat simpulan terhadap pembelajaran. Selesai pembelajaran siswa langsung membubarkan diri tanpa ada evaluasi atau menyampaikan materi pada pertemuan berikutnya.

Dalam hal ini diperoleh bahwa guru I dalam menerapkan pendekatan saintifik Sangat baik dengan persentase $90 \%$, guru II dalam kategori cukup baik dengan persentase $77,5 \%$, begitu juga dengan guru III dalam kategori cukup baik dengan persentase $75 \%$. Maka, dapat disimpulkan bahwa penerapan pendekatan saintifik yang dilaksanakan di SMP Negeri 2 Secanggang sudah cukup baik.

Dari pernyataan tersebut diketahui bahwa aspek 5M yang ada pada pendekatan santifik yang paling dominan guru hanya melaksanakan 3M dengan baik yaitu mengamati, mengumpulkan informasi atau mencoba dan mengkomunikasikan atau menyajikan dalam pembelajaran bahasa Indonesia. Sedangkan untuk kegiatan menanya guru masih kesulitan dalam menerapkannya dan kegiatan menalar masih banyak komponen yang belum diterapkan oleh guru pada saat pembelajaran.

\section{PENUTUP}

Berdasarkan hasil analisis data pada penelitian ini, maka penulis mengambil beberapa kesimpulan yaitu guru I dalam menerapkan pendekatan saintifik sudah terbilang baik dengan persentase $90 \%$. Karena dilihat dari cara guru I dalam mengelola kelas, ia mampu membuat suasana kelas jadi hidup. Terlihat siswa juga aktif bertanya dan memberikan tanggapan. Pendekatan saintifik berupa mengamati, menanya, mencoba, menalar, dan mengomunikasikan sudah berjalan dengan baik oleh guru I, walaupun masih ada yang belum tercapai.

Guru II dalam menerapkan pendekatan saintifik sudah terbilang cukup baik dengan persentase 77,5 \% terlebih lagi mengingat guru II belum mengikuti pelatihan Kurikulum 2013. Secara keseluruhan dilihat bahwa pendekatan saintifik yang dilaksanakan oleh guru II sudah berjalan dengan baik.

Guru III dalam menerapkan pendekatan saintifik sudah terbilang cukup baikdengan persentase $72,5 \%$. Karena pendekatan saintifik yang 
dilaksanakan oleh guru III masih belum semuanya terpenuhi, masih ada beberapa poin-poin pada pendekatan saintifik yang masih belum terlihat.

$$
\text { Hasil penelitian }
$$

memperlihatkan bahwa guru yang mengajar sudah menerapkan pendekatan saintifik dengan cukup baik saat pembelajaran. Namun, masih belum sempurna. Dari aspek 5M yaitu mengamati, menanya, mencoba, menalar, dan mengomunikasikan yang ada di pendekatan santifik guru rata-rata hanya melaksanakan 3M yaitu mengamati, mengumpulkan informasi ataumencoba, dan mengkomunikasikan atau menyajikan dalam pembelajaran bahasa Indonesia. Dalam pelaksanaan kegiatan pendahuluan dan penutup, guru masih belum sempurna dalam melaksanakannya.

Berdasarkan hasil penelitian yang dilakukan diharapkan bagi sekolah dan guru agar semakin meningkatkan pembelajaran Bahasa Indonesia dengan menggunakan pendekatan saintifik. Guru harus benar-benar mampu memahami langkah-langkah penerapan pendekatan saintifik yang lebih baik lagi, sehingga dapat tercipta situasi belajar yang dapat membuat siswa lebih aktif dan berkonsentrasi, dan siswa tidak merasa jenuh dan mengingat keterbatasan penelitian ini, maka penulis menyarankan pada peneliti yang lain dapat meneliti hal yang sama pada sekolah-sekolah yang lain agar dapat dijadikan studi perbandingan guru dalam meningkatkan mutu dan kualitas pada pembelajaran bahasa Indonesia.

\section{DAFTAR PUSTAKA}

Abidin, Yunus. 2016. Desain Sistem Pembelajaran Dalam Konteks Kurikulum 2013. Bandung: PT Refika Aditama

Bintara, Ni Luh Gede Riwan Putri, dkk. (2014). Pembelajaran Bahasa Indonesia Berdasarkan Pendekatan Saintifik (Problem Based Learning) Sesuai Kurikulum 2013 di Kelas VII SMP Negeri 2 Ampalapura. EJournal Program Pascasarjana Universitas Pendidikan Ganesha. Vol. 3. http://ejournal.undiksha.ac.id/ksk/ind ex.rkl/aahi, diakses pada tanggal 20 Maret 2018

Darnius, Said. (2016). Identifikasi Kesulitan Guru Dalam Mengimplementasikan 
Kurikulum 2013 Dengan

Pendekatan Saintifik di Kelas

Tinggi Gugus Mangga Kecamatan Jaya Baru Banda Aceh. Jurnal Pesona Dasar Pendidikan Guru Sekolah Dasar (PGSD) Universitas Syah Kuala. Vol. 2 No. 4, April 2016. Hal $40-48$. http://jurnalunsyiah.ac.id/ttc/i ndeks.php/aac, diakses pada tanggal 07 Novemmber 2018

Daryanto. (2014). Pendekatan Pembelajaran Saintifik Kurikulum 2013. Yogyakarta: Gava Media

Hosnan. 2014. Pendekatan Saintifik dan Kontekstual Dalam Pembelajaran Abad 21. Bogor: Ghalia Indonesia

Majid, Abdul dan Rochman, C. (2015). Pendekatan Ilmiah dalam Implementasi Kurikulum 2013. Bandung : Remaja Rosdakarya

Muliatina. (2016). Kendala Guru dalam Menerapkan
Pendekatan Saintifik pada Kurikulum 2013 di SDN TEUPIN PUKAT MEUREUDU PIDIE JAYA. Jurnal Ilmiah Mahasiswa Prodi PGSD FKIP UNSYIAH. Vol. 1 No. 1, hal. 129-136. $\quad$ http://ejournal.fkipunsyiah.ac.id//ert, diakses pada tanggal 1 Juli 2018

Peraturan Menteri Pendidikan dan Kebudayaan Republik Indonesia Nomor 81A Tahun 2013 Tentang Implementasi Kurikulum 2013

Purnama, Aryani, dkk (2016). Implementasi Pembelajaran Berpendekatan Saintifik: Keterampilan Guru Mata Pelajaran Bahasa Indonesia. Jurnal METAFORA Pascasarjana Universitas Muhammadiyah Surakarta Jawa Tengah, Indonesia. Vol.2 No. 2 http://ejournal.metafora.ac.id/afg/ind ex.ddc/ert, diakses pada tanggal 20 Maret 2018 